$$
\begin{gathered}
\text { 수두 유행을 평가하기 위한 신규 지표 개발 } \\
\text { 양기욱 }{ }^{1}, \text { 서인철 }^{2} \\
{ }^{1} \text { 계명대학교 의과대학 해부학교실, }{ }^{2} \text { 대구광역시청 보건건강과 }
\end{gathered}
$$

\title{
Developing a new index to assess varicella outbreak
}

\author{
Kiwook Yang ${ }^{1}$, Incheol Seo ${ }^{2}$ \\ ${ }^{I}$ Department of Anatomy, Keimyung University School of Medicine; ${ }^{2}$ Public Health \& Welfare Bureau, \\ Daegu Metropolitan City, Daegu, Korea
}

\begin{abstract}
Background: Varicella is the most common infectious disease reported despite the high vaccination rate. Interventions that target humans are particularly effective for varicella because humans are its only natural host. On the other hand, the existing national varicella surveillance systems lack the information to identify an outbreak. Therefore, a new index to assess varicella outbreaks was developed.

Methods: The residential addresses of 2,718 varicella cases reported in Daegu in 2016 were converted to geographic coordinates and the distances between new varicella case and previous cases within 21 days were calculated from the date analyzed. Two cases were considered to be adjacent if the distance between them was less than $1 \mathrm{~km}$. Finally, a proximity index was introduced by dividing the number of adjacent cases by the number of new cases on the date analyzed.

Results: First, time-series charts and scatter plots were used to verify that the proximity index reflected the spatial closeness of the different varicella cases. The proximity index is helpful in identifying outbreaks from a list of single varicella cases. In addition, in this study, a new epidemic characteristic of varicella based on the proximity index was shown.

Conclusion: The proximity index introduced in this study can be used to determine the likelihood of an outbreak from a single case of varicella, and it can be embedded in a web-based national varicella surveillance system that is currently in operation.
\end{abstract}

Keywords: Varicella; Varicella-zoster virus; Disease control; Proximity; Index

\section{서 론 \\ 수두는 국가필수예방접종 대상 감염병으로 2016년 국내}

Received: September 20, 2017, Revised: November 9, 2017 Accepted: November 15, 2017

Corresponding Author: Incheol Seo, Public Health \& Welfare Bureau, Daegu Metropolitan City, 88 Gongpyeong-ro,

Jung-gu, Daegu 41911, Korea

Tel: +82-53-803-6288, Fax: +82-54-004-1601

E-mail: 053@korea.kr
에 거주하는 만 3세 아동의 수두 백신 접종률은 $97.5 \%$ 이다 [1]. 그러나 높은 예방 접종률에도 불구하고 수두는 가장 흔 히 발생하는 법정감염병으로 전국에서 연간 4-5만 건의 신규 발생이 보고된다[2]. 뿐만 아니라, 어린이집, 유치원 등의 집 단 보육 시설을 이용을 하는 아동의 수가 증가함에 따라 수두 는 해마다 증가하고 있는 상황이다[2,3].

수두는 사람 간의 직접 접촉이 유일한 전파 방법인 감염병 이기 때문에 사람 이외의 감염 매개체가 존재하거나 자연이 나 환경에 대한 동시 조사와 관리가 필요한 인수공통감염병

Copyright (C) 2017 Yeungnam University College of Medicine

This is an Open Access article distributed under the terms of the Creative Commons Attribution Non-Commercial License (http://creativecommons.org/licenses/by-nc/4.0/) which permits unrestricted non-commercial use, distribution, and reproduction in any medium, provided the original work is properly cited. 
이나 수인성전염병 등과는 달리 개별 수두 감염자에 대한 조사와 분석을 통해 질병의 전파 경로를 추정하고 전파를 차단하는데 유리함이 있는 감염병이다[4]. 그러나 사람간 직 접접촉에 의한 감염이 유일한 전파 방법임에도 불구하고 현재 의 감염병 감시 체계하에서 신고되는 거의 모든 수두는 개별 발생 사례로 결론 내려지고 있으며, 그 전파 경로를 추정할 수 없는 경우가 대부분이다(내부자료). 질병관리본부에서 발 간한「예방접종 대상 감염병 사업관리 지침」에 따르면 수두 유행 사례에 대한 정의 및 역학조사의 시행기준은 "수두환자 (의사환자 포함)가 2명 이상 역학적으로 연관된(시간적, 공간 적으로 밀집) 경우”, “학교, 유치원, 영유아 보육시설 등에서 의 유행은 3 주 이내 1 개 학급에서 수두(의사)환자가 해당 학 급 전체 인원의 $5 \%$ 이상 발생한 경우”로 정해져 있다[5]. 그 러나 현재의 수두 감시 체계에서 수두를 포함한 법정감염병 의 신고의무는 의료기관 등에 있고, 50 종 이상의 법정감염병 이 「감염병 발생 신고서」라는 단일서식을 통해서 신고되고 있어 감염자의 소속 집단이나 학년, 학급 등은 신고의무 대상 항목이 아니다. 따라서 유치원, 학교 등에서 직접 수두의 유행 을 인지하고 집단 발생을 신고하기 전까지는 수두 유행 사례 를 찾아낼 방법이 없다. 그렇다고 해서 실무 현장에서 의료기 관이 수두 발생으로 신고한 모든 학령전기, 학령기 아동의 사례에 대해서 보건소가 전화 조사 등을 통하여 소속 집단과 학년, 학급을 확인하고 수정 보고하는 방법으로 유행을 판단 하는 것은 불가능하다.

따라서 이 연구는 기존의 수두 감시 체계하에 의료기관을 통해 기본적으로 확보되는 정보인 수두 발생 보고일과 감염자 의 거주지 주소라는 시간공간 정보를 활용하여 개별 수두 발 생 보고 사례 중에서 수두 유행 의심 사례를 판단하는데 도움 이 되는 새로운 지표를 개발하는 것을 목적으로 시행되었다.

\section{재료 및 방법}

\section{1. 대상}

「감염병의 예방 및 관리에 관한 법률」에 따라 수두 확진 또는 의사 환자로 보건소 또는 질병보건통합관리시스템으로 신고된 사례 중 대구 지역에서 2015년 12월 11일부터 2016년 12 월 31일까지 신고된 2,718 사례를 연구의 대상으로 설정 하였다[6. 연구 대상의 수두 발생보고일, 거주지 주소를 질병 보건통합관리시스템으로부터 제공받고 거주지 주소는 위도. 경도로 변환한 후 삭제하였다[7]. 법정감염병 신고 정보를
연구 목적으로 사용하는 것은 역학조사관의 고유 업무에 해당 하며, 이 연구에서 활용된 정보는 연구 대상의 개인식별정보 가 제거된 형태이므로 계명대학교 동산병원 기관윤리심의위 원회를 통해 심사면제를 승인받을 수 있었다(DSMC 201707-048) [6].

\section{2. 방법 및 통계분석}

지표 개발과 통계분석 및 도표 작성의 전 과정에서 R version 3.3.3과 ggmap, ggplot2, grid, gridExtra, MASS, scales 패키지를 활용하였다[8]. 자세한 분석의 과정은 Fig. 1과 같다. 먼저 2,718 사례의 거주지 주소(Fig. 1A)를 R의 geocode() 함수를 이용하여 Google Maps Geocoding application programming interface (API)를 경유하여 위도와 경도로 변환하였다 (Fig. 1B) [9]. 이후 R에서 반복명령문을 작성하여 수두 발생 보고일을 기준으로 2016년 1월 1일부터 12월 31일까지 일별 수두 발생 보고 사례를 추출(Fig. 1C, 1D)하고 분석 기준일과 기준일로부터 기존의 유행역학조사의 기준이며, 수두의 최 대 잠복기인 21일 이내에 보고된 사례(Fig. 1E)를 추출한 후 분석 기준일의 수두 발생 사례와 이전 21일 내에 보고된 사례 간의 최단거리(great-circle distance)를 위도, 경도 정보를 활 용하여 계산하였다(Fig. 1F). 두 지점 간의 거리는 지구를 반 지름이 $6,378.145 \mathrm{~km}$ 인 완전한 구체로 가정하고 haversine formula로부터 유도된 아래의 식을 R에서 함수로 만들어 계 산하였다[10].

$$
d=2 r \cdot \arcsin \left(\sqrt{\sin ^{2}\left(\frac{\phi_{1}-\phi_{2}}{2}\right)+\cos \left(\phi_{1}\right) \cos \left(\phi_{2}\right) \sin ^{2}\left(\frac{\lambda_{2}-\lambda_{2}}{2}\right)}\right)
$$

$\mathrm{d}$ 는 구체 표면의 두 지점을 연결하는 대원의 호의 길이 $(\mathrm{km})$ $\mathrm{r}$ 은 구체의 반지름 $(6,378.145 \mathrm{~km}), \phi$ 는 위도, $\lambda$ 는 경도

위 방법으로 분석 기준일의 수두 발생 사례와 최대 잠복기 이내에 발생한 수두 사례 간의 거리를 모두 계산하여 그 중에 서 $1 \mathrm{~km}$ 이내의 거리에 있는 사례의 수를 추출하고 분석 기준일의 수두 발생 사례 수로 나누어 근접도(proximity)라 는 지표를 산출했다(Fig. $1 \mathrm{G}$ ). 근접도 지표는 분석 기준일에 보고된 수두 발생 사례에서 통상 생활 반경 내에 존재하는 수두의 평균 발생 사례 수를 의미한다. 이 연구에서는 수두가 학령전기, 학령기 아동에서 주로 발생한다는 특성을 고려하 여 통상생활반경은 $1 \mathrm{~km}$ 로 설정하였고, 최대 잠복기 내에 근 접하여 발생한 사례를 구별하는 기준거리로 사용하였다.

근접도 지표가 신규 수두 발생과 기존에 발생한 수두의 인접한 정도를 잘 나타내는지를 검증하기 위해서 분석 대상 
기간 전체의 근접도 지표 365 개의 계산 과정과 지표 계산을 위해서 분석에 포함된 사례(분석 기준일의 수두 발생 사례, 분석 기준일로부터 21일 이내 발생 사례, 통상생활반경 이내
에 위치한 발생 사례)들을 지도상에서 직접 표시하여 육안으 로 사례들 간의 인접한 정도를 확인하였다. 이때, 연구 대상자 를 보호하기 위하여 배경지도는 삭제하고 위도, 경도에 따른
(A) Varicella report list

\begin{tabular}{|c|c|c|}
\hline \multicolumn{3}{|c|}{ Varicella reports (examples) } \\
\hline ID & Date of report & Home address \\
\hline 1 & $2015 / 12 / 11$ & 111, Daegu, Korea \\
\hline 2 & $2015 / 12 / 19$ & 222, Daegu, Korea \\
\hline 3 & $2015 / 12 / 31$ & 123, Daegu, Korea \\
\hline 4 & $2016 / 01 / 01$ & 135, Daegu, Korea \\
\hline 5 & $2016 / 01 / 02$ & 266, Daegu, Korea \\
\hline 6 & $2016 / 01 / 02$ & 300, Daegu, Korea \\
\hline 7 & $2016 / 01 / 03$ & 450, Daegu, Korea \\
\hline 8 & $2016 / 01 / 05$ & 199, Daegu, Korea \\
\hline$\vdots$ & $\vdots$ & $\vdots$ \\
\hline 2718 & $2016 / 12 / 31$ & 222, Daegu, Korea \\
\hline
\end{tabular}

(C) Extraction of reports to be analyzed

\begin{tabular}{|c|c|c|c|}
\hline \multicolumn{5}{|c|}{ Varicella reports (examples) } \\
\hline ID & Date of report & Latitude & Longitude \\
\hline 1 & $2015 / 12 / 11$ & 36.259552 & 129.996667 \\
\hline 2 & $2015 / 12 / 19$ & 36.268325 & 130.055678 \\
\hline 3 & $2015 / 12 / 31$ & 36.260629 & 130.146029 \\
\hline 4 & $2016 / 01 / 01$ & 36.265281 & 130.133585 \\
\hline 5 & $2016 / 01 / 02$ & 36.263065 & 130.080588 \\
\hline 6 & $2016 / 01 / 02$ & 36.269102 & 130.052460 \\
\hline 7 & $2016 / 01 / 03$ & 36.264887 & 130.113260 \\
\hline 8 & $2016 / 01 / 05$ & 36.262916 & 130.171602 \\
\hline$\vdots$ & & $\vdots$ & $\vdots$ \\
\hline 2718 & $2016 / 12 / 31$ & 36.269152 & 130.129046 \\
\hline
\end{tabular}

\begin{tabular}{|c|c|c|c|c|}
\hline \multicolumn{5}{|c|}{ (B) Address to latitude \& longitude } \\
\hline \multirow{7}{*}{ geocode() in $\mathrm{R}$} & \multicolumn{4}{|c|}{ Varicella reports (examples) } \\
\hline & ID & Date of report & Latitude & Longitude \\
\hline & 1 & $2015 / 12 / 11$ & 36.259552 & 129.996667 \\
\hline & 2 & $2015 / 12 / 19$ & 36.268325 & 130.055678 \\
\hline & 3 & $2015 / 12 / 31$ & 36.260629 & 130.146029 \\
\hline & 4 & $2016 / 01 / 01$ & 36.265281 & 130.133585 \\
\hline & 5 & 2016/01/02 & 36.263065 & 130.080588 \\
\hline \multirow{5}{*}{$\begin{array}{l}\text { Google Maps } \\
\text { Geocoding API }\end{array}$} & 6 & $2016 / 01 / 02$ & 36.269102 & 130.052460 \\
\hline & 7 & $2016 / 01 / 03$ & 36.264887 & 130.113260 \\
\hline & 8 & $2016 / 01 / 05$ & 36.262916 & 130.171602 \\
\hline & $\vdots$ & $\vdots$ & $\vdots$ & $\vdots$ \\
\hline & 2718 & $2016 / 12 / 31$ & 36.269152 & 130.129046 \\
\hline
\end{tabular}

(D) Reports of the date to be analyzed

(F) Generation of distance field

\begin{tabular}{|c|c|c|c|c|c|c|c|c|}
\hline \multicolumn{10}{|c|}{ Varicella reports (examples) } \\
\hline ID & Date of report & Latitude & Longitude & ID & Date of report & Latitude & Longitude & Distance (Km) \\
\hline 5 & $2016 / 01 / 02$ & 36.263065 & 130.080588 & 2 & $2015 / 12 / 19$ & 36.268325 & 130.055678 & 2.311 \\
\hline 5 & $2016 / 01 / 02$ & 36.263065 & 130.080588 & 3 & $2015 / 12 / 31$ & 36.260629 & 130.146029 & 5.880 \\
\hline 5 & $2016 / 01 / 02$ & 36.263065 & 130.080588 & 4 & $2016 / 01 / 01$ & 36.265281 & 130.133585 & 4.763 \\
\hline 6 & $2016 / 01 / 02$ & 36.269102 & 130.052460 & 2 & $2015 / 12 / 19$ & 36.268325 & 130.055678 & 0.301 \\
\hline 6 & $2016 / 01 / 02$ & 36.269102 & 130.052460 & 3 & $2015 / 12 / 31$ & 36.260629 & 130.146029 & 8.451 \\
\hline 6 & $2016 / 01 / 02$ & 36.269102 & 130.052460 & 4 & $2016 / 01 / 01$ & 36.265281 & 130.133585 & 7.294 \\
\hline
\end{tabular}

(G) Statistics

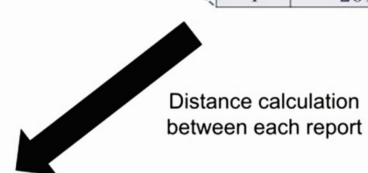

Varicella reports (examples)

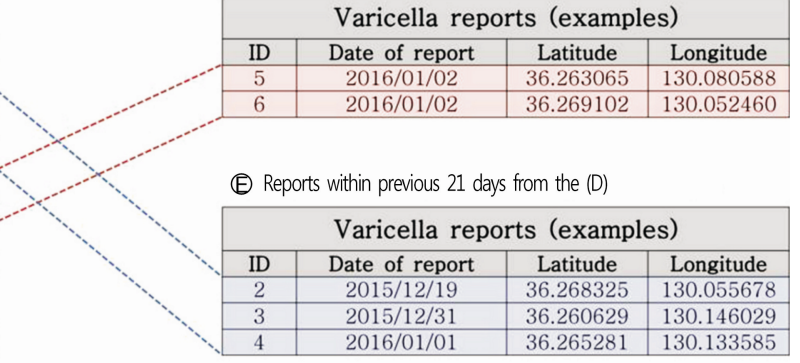

Distance calculation

\begin{tabular}{|c|c|c|c|c|}
\hline \multicolumn{5}{|c|}{ Statistics } \\
\hline Date & No. of reports & $\begin{array}{c}\text { No. of reports within } \\
\text { previous 21 days }\end{array}$ & $\begin{array}{c}\text { No. reports within previous 21 days } \\
\text { within a radious of 1 Km }\end{array}$ & Proximity \\
\hline$\vdots$ & $\vdots$ & $\vdots$ & $\vdots$ & $\vdots$ \\
\hline $2016 / 01 / 02$ & 2 & 3 & $\vdots$ & 0.5 \\
\hline$\vdots$ & $\vdots$ & $\vdots$ & $\vdots$ & $\vdots$ \\
\hline
\end{tabular}

Fig. 1. Proximity index calculation. (A) Extraction of report dates and home addresses from a national varicella surveillance system. (B) Address conversion to latitude and longitude. (C-E) Extraction of new cases with the date to be analyzed and previous cases within 21 days. (F) Calculation of distances between new and previous cases. Two cases were considered to be adjacent if the distance between them was less than $1 \mathrm{~km}$. (G) Proximity index calculated by dividing the number of adjacent cases by the number of new cases on the date analyzed. 
산점도 형식으로 그래프를 생성하였다(Fig. 2B-2E). 산점도 에서 사례들 간의 집중도를 확인하기 위해서 산점도 위에 밀도 도표를 덧입혔으며, 일별 수두 발생과 일별 근접도 지표 의 시계열적 변화를 함께 분석하기 위한 선도표(Fig. 2A)를 생성하였다. R의 반복명령문으로 생성된 365 개의 산점도와 시계열 도표는 동영상으로 변환되어 개발된 지표의 신뢰성 분석과 지표를 이용한 수두 발생의 시계열적 특성의 육안분 석에 활용되었다(미공개자료).

\section{결 과}

\section{1. 수두 관리 지표 개발 및 검증}

2016년 1월 1일부터 12월 31일까지 일일 수두 보고 사례 수와 근접도 지표의 시계열도표는 Fig. $2 \mathrm{~A}$ 와 같다. 도표에서 연한 붉은색 면으로 채색된 선 도표는 일별 수두 사례 수를 나타내며 연한 푸른색 면으로 채색된 선 도표는 일별 근접도 를 나타낸다. 수두 신고가 병의원에 의해 이루어지기 때문에 일주일 중 토요일과 일요일에는 신고 사례 수가 감소한다. 그로 인해 일별 수두 보고 사례 수와 일별 근접도의 주중 변동이 발생하게 되므로 일별 분석 자료를 이용해서는 신고 사례 수와 근접도 간의 관계를 파악하기 어렵다. 따라서 이를 해결하기 위해 신규 수두 발생 사례 수와 근접도의 7일 이동 평균을 구하여 각기 붉은색과 푸른색의 선 도표로 표시하였 다. 7 일 이동평균 선 도표를 기준으로 수두 발생 사례 수와 근접도는 유사한 형태의 주기적인 변화와 연중 변화양상을 보였다. 근접도는 수두 발생 사례 수에 비슷하거나 더 작았으 며 큰 경우는 드물었다. 선 도표의 수두 발생 사례 수와 근접 도를 위도·경도 산점도와 비교할 때 근접도 지표가 신규 발생 된 수두와 기존 발생한 수두의 인접한 정도를 잘 나태내고 있음을 확인할 수 있었다(Fig. 2B-2E). 산점도에서 빨간색 원은 분석 기준일에 보고된 수두 발생 사례의 위치이며, 초록 색원은 기준일로부터 최대 잠복기인 21 일 이내에 보고된 수 두 사례의 위치, 노랑색원은 최대 잠복기 이내에 보고된 수두 사례 중 분석 기준일의 사례로부터 반경 $1 \mathrm{~km}$ 이내에 존재하 는 수두 사례를 나타낸다.

\section{2. 근접도 지표를 활용한 수두 발생 양상 분석}

지표 개발을 위해 분석 대상으로 사용된 1년 간의 수두 발생 사례와 그로부터 도출된 근접도의 시계열 선 도표에서 수두
의 발생에 여러 유형이 존재함을 발견할 수 있었다(Fig. $2 \mathrm{~B}-2 \mathrm{E})$. 수두 발생 보고는 여름과 겨울에 증가하며, 봄과 가을 에 감소하는 양상을 보여 온대 기후에서의 수두 발생양상에 대한 기존 지식과 일치하였다[3]. 근접도는 봄과 여름에는 수두 발생 사례 수와 비슷한 수준으로 확인되었고, 가을과 겨울에는 발생 사례 수보다 작게 확인이 되었다. 따라서 근접 도 지표를 활용하여 수두의 발생의 많고 적음, 근접도와 발생 수의 일치, 불일치 여부에 따라 총 4 가지 수두 발생 유형을 확인할 수 있었다. 첫 번째는 수두 발생이 적고 근접도가 발생 수와 일치하는 유형(Fig. 2B), 두 번째로 수두 발생이 많고 근접도가 일치하는 유형(Fig. 2C), 세 번째로 수두발생이 적 고 근접도가 불일치하는 유형(Fig. 2D), 마지막으로 수두발생 이 많고 근접도가 불일치하는 유형(Fig. 2E)이 확인되었다.

\section{고 찰}

수두는 herpesvirus family에 속하는 varicella-zoster virus 에 의해서 발생하는 감염병으로 초회 감염 시 온몸에 특징적 인 피부 반점이 관찰되는 전염성질환이다[3]. 수두는 수두 환자의 수포액과 직접 접촉하거나 호흡기 분비물을 통한 직 접 접촉에 의해 전파된다. 수두는 사람이 유일한 감염원이므 로 인수공통감염병 등과 다르게 역학적 특성에 대한 심도있 는 분석을 통해서 수두의 발생을 효과적으로 통제할 수 있을 것으로 예측되어진다[4]. 그럼에도 불구하고 현재의 수두 관 리 체계하에서 실무 현장의 수두 발생 신고 사례를 검토하여 도 유행 여부를 판별하기 어렵고, 전파 차단을 위해서 시급한 조치가 필요한 발생 사례가 어떤 것인지 파악하기 어렵다. 실제로 대구 지역에서 보고되는 수두 확진 또는 의사환자 사례는 연간 2 천건 이상이지만, 그 중 10-20명의 사례만이 집단 감염으로 결론 내려지며, 나머지 $99 \%$ 이상의 사례는 개별감염 사례로 처리가 된다. 전염력이 매우 강하며, 사람 간의 직접 전파가 유일한 감염경로로 알려진 수두의 역학적 특성을 고려한다면 $1 \%$ 미만의 사례만이 유행 사례로 정의되 는 것에 대한 고찰이 필요하다. 수두의 유행을 파악하기 위해 서 개별 사례의 소속 집단과 소속 학급에 대한 전수조사를 매일 실시하는 것은 실무적으로 어렵다. 개별 발생 사례의 거주지 주소 정보를 활용하여 수두가 어느 지역에서 많이 발생하고 있는지, 최대 잠복기인 21일 이내에 인접 지역에 얼마나 많은 수두가 발생하였는지를 지도에 일일이 표시해 보는 수동적인 방법 또한 많은 시간과 자원의 투입을 요구하 므로 소수의 감염병 담당자가 50 종 이상의 법정감염병을 관 


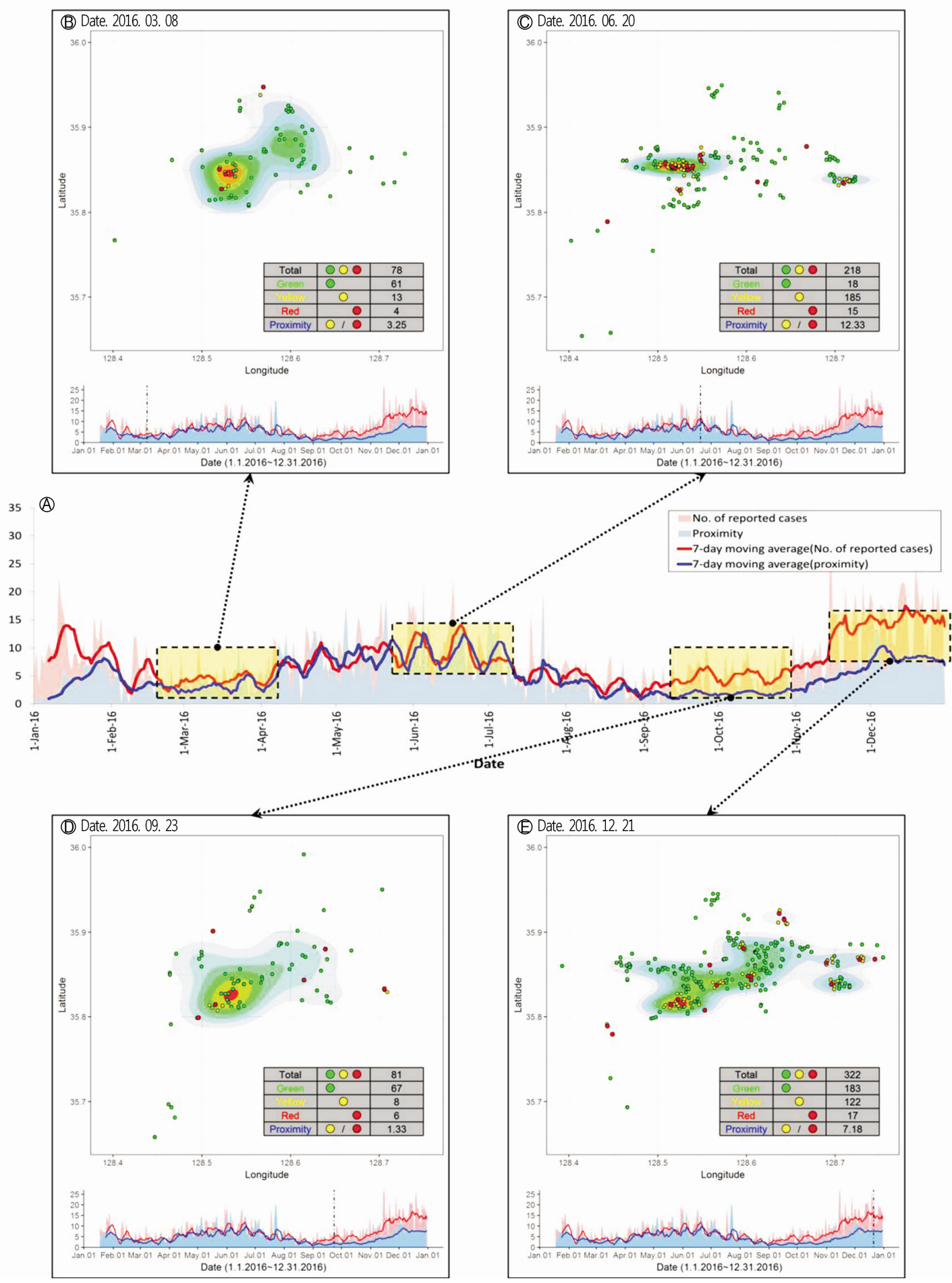

Fig. 2. The time series of varicella, the proximity index, and the corresponding scatter plots. (A) The charts in light red and light blue indicate the number of daily varicella reports and the proximity index, respectively. Red and blue lines indicate the 7-day moving averages of the varicella cases and the proximity index, respectively. (B-E) Scatter plots show the residences of people infected with varicella. The red, green, and yellow circles, respectively, indicate the newly reported varicella cases, previous cases reported within 21 days from the analysis date, and cases reported both within previous 21 days from the analysis date and cases within a 1-km radius of new cases. 
리하고 있는 상황에서 실무에 적용되기 어렵다. 따라서 이 연구에서는 현재의 수두 관리 체계하에서 수집되는 정보인 수두 발생의 시간적, 공간적 정보를 활용하여 수두 유행을 파악할 수 있는 새로운 지표를 개발하고자 하였다.

기존에 공간 정보를 갖는 데이터를 분석하는 기법으로 공 간 상의 현상에서 상호의존성과 상호작용에 대해 공간자기 상관(spatial autocorrelation)이라는 개념이 도입되었고, 이를 통계량으로 나타내는 대표적인 방법에는 Moran's I (Moran's autocorrelation coefficient)가 있다[11,12].

$$
\text { Moran's } I=\frac{n}{S_{0}} \frac{\sum \sum W_{i j}\left(X_{1}-\bar{X}\right)\left(X_{j}-\bar{X}\right)}{\sum\left(X_{i}-\overline{X^{2}}\right)}
$$

$\mathrm{n}:$ 관측 갯수

$w_{i j}$ : 관측치 $i$ 와 $j$ 사이의 가중치

$\mathrm{S}_{0}: \mathrm{W}_{\mathrm{ij}}$ 의 총합

그러나 실무에서 수두의 유행을 판별하는데 Moran's I 통 계량을 사용하기에는 몇 가지 어려움이 존재한다. 가장 먼저 -1 에서 +1 까지의 값으로 표시되는 Moran's I는 수두 발생의 공간적 분포가 임의적이라는 영가설을 검증하기 위한 통계 량으로 사용되어야 하며, I값 그 자체로 특정한 의미나 해석 이 부여될 수 없기 때문에 실무적 사용과 해석에 어려움이 존재한다. 따라서 실무자에 의한 수두 관리에서 학술적 의의 가 높은 지표보다는 쉽게 이해하고 실무에 활용할 수 있는 간편한 지표가 필요하다. 두 번째로 Moran's I를 이용한 수두 발생의 공간자기상관을 확인하는 것은 분석 기준일에 보고 된 수두의 집적도를 반영하지 못한다. 신규 발생된 수두 사례 의 추정 감염의 시기는 발생 보고 시점으로부터 최대 잠복기 이내인 21일이다. 따라서 분석의 대상이 되는 수두 발생 사 례로부터 21일 이전까지의 사례들에 의한 Moran's I를 산출 할 때, 분석에 사용된 사례(분석 기준일로부터 21일 이전 이내 에 발생한 사례)들의 공간적인 근접도는 확인할 수 있으나 그것이 신규로 발생한 수두와 얼마나 근접하여 발생한 것인 지를 반영하는 지표가 되지 못한다. 만약 분석 당일 발생한 수두를 포함하여 공간자기상관 통계량 I를 계산하여도 여전 히 기존에 발생한 21 일 간의 공간적 근접성에 의한 영향으로 분석 기준일의 수두 발생이 얼마나 기존의 사례들과 근접해 있는지 확인할 수는 없다. 따라서 실무자들이 쉽게 이해할 수 있으면서 신규 수두 발생사례가 기존에 발생한 수두 사례 로부터 얼마나 인접해 있는지 직접적으로 나타낼 수 있는 지표를 개발할 필요가 있다.

이 연구에서는 신규 보고된 수두 사례에서 최대 잠복기
이내에 통상생활반경 안에 기존 보고된 수두 발생 사례가 얼마나 있는지 확인하여 정량화하는 것을 기본 원리로 하는 지표를 개발하기 위해서 2016년 대구 지역에서 보고된 수두 감염 사례 2,718 건에 대한 분석을 실시하였다. 최대 잠복기 는 21일, 통상생활반경은 $1 \mathrm{~km}$ 로 설정하고, $\mathrm{R}$ 에서 반복문을 작성하여 분석 대상 기간인 365 일에 대해 일별 최대 잠복기 이내 통상생활반경 안의 수두 발생 보고의 수를 분석 기준일 의 수두 발생 보고 수로 나누는 방법을 통해 정량화된 지표를 산출하였고, 근접도라고 명명하였다(Fig. 1). 근접도는 신규 발생된 수두 개별 사례들에서 최대잠복기 이내에 통상생활 반경 내에서 발생한 기존의 수두 발생의 평균 수를 직접적으 로 나타내기 때문에 수두 발생 보고 수와 단위가 일치하므로 통계지식이 없는 실무자들도 쉽게 이해할 수 있는 지표로 판단된다.

근접도라는 정량적 지표가 개별 보고된 수두 사례가 유행 에 의한 발생일 가능성이 있는지 판단하는데 도움이 될 수 있는지 확인하기 위해서 분석 기준일의 수두 발생 사례와 최대 잠복기 이내의 수두 발생 사례, 인접하여 보고된 수두 발생 사례를 위도와 경도 기준으로 산점도로 작성하고 근접 도 지표와 비교하였다. 분석 기준일의 수두 발생 보고 수에 준하는 높은 근접도를 나타낸 Fig. $2 \mathrm{~B}$ 와 $2 \mathrm{C}$ 에서는 새로이 발생한 수두(산점도의 빨간원)가 기존의 수두(초록색원)와 인접하여 발생(노랑색원)하는 것이 확인되었다. 반면, 분석 기준일의 수두 발생 보고 수에 비해서 낮은 근접도를 나타낸 Fig. $2 \mathrm{D}$ 와 $2 \mathrm{E}$ 에서는 새로이 발생한 수두가 기존의 수두 발생 보고 지역으로부터 상대적으로 원거리에서 발생하였음을 확 인할 수 있었다. 분석 대상 기간 전체 365 일에 대해서 산점도 를 작성하여 시계열 동영상으로 변환하여 선 도표와 비교하 였을 때 선 도표에 표시된 근접도와 산점도의 수두 발생 양상 이 일치함을 확인할 수 있었다. 따라서 근접도 지표를 활용하 면 역학조사관이나 감염병 관리자가 개별 수두 발생 사례를 지도상에 표시하여 발생 양상을 직접 눈으로 확인하거나 개 별 사례 전체에 대한 간이 조사를 통해 유행의 가능성을 판별 할 필요 없이 정량화된 지표를 확인함으로써 현재 발생하고 있는 수두가 광범위한 지역에 걸쳐 발생하는지, 특정 지역에 서 집중적으로 발생하는 지를 추정하는 것이 가능하다.

이 연구에서 개발된 근접도 지표는 기존의 수두 신고 체계 하에서 확보되어 오던 정보를 활용하여 새로운 지표를 생성 한 것이기 때문에 실무에 적용할 때 요구되는 노력이나 비용 이 거의 없다. 실제로 이 연구에서 근접도를 계산하기 위해서 Google에서 제공하는 API 서비스를 활용하고 추가적인 간단 
한 연산만이 시행되었으므로 근접도 지표를 현재 질병관리 본부에서 운용중인 웹기반의 법정감염병 신고·감시 체계에 내장(embed)하여 실무자에게 제공하는데 어려움이 없다. 또 한, 이 연구에서 도출된 근접도는 인구밀도가 높은 지역에서 사람간 전파되는 감염병의 위험성이 더 높다는 당연한 특성 을 그대로 반영하는 수치이기 때문에 Moran's I가 공간적 독립성을 가정하지 않는 통계량임에도 불구하고, 인구밀도 가 특히 높고 아파트에 거주하는 인구 수가 집중적으로 많은 우리나라의 사회적 특성으로 인하여 Moran's I를 이용한 공 간자기상관분석이 어렵다는 문제로부터 자유롭다.

이러한 장점과 반대로 이 연구에는 몇 가지 한계점이 존재 한다. 첫 번째로 이 연구에서는 2016년 보고된 수두 발생 2,718 사례를 분석의 원시자료로 사용하였는데, 원시자료에 는 수두 발생 보고의 누락, 또는 오진에 의한 수두가 아닌 사례가 포함되어 있을 수 있다. 수두 발생 보고의 의무가 의사나 한의사 등 의료인에 있어서 실험실적으로 또는 임상 적으로 진단된 수두 환자 및 의사환자는 모두 신고되도록 법으로 규정하고 있음에도 불구하고 의료인의 업무 미숙에 의한 신고 누락, 수두 이외의 질환의 수두로의 오신고 등의 가능성을 배제할 수 없다. 그럼에도 불구하고 임상에서 대부 분의 수두 사례에서 확진을 위한 실험실 검사가 실시되지 않기 때문에 이 연구에서 사용된 원시자료는 2016년 대구지 역의 수두 발생에 대한 가장 정확한 자료라 할 수 있다. 두 번째로 이 연구에서 생성한 근접도 지표는 수두의 실제 발생 장소가 아니라 수두 감염자의 거주지 주소를 기반으로 분석 하였다는 한계가 있다. 가족 내 전염이 아닌 이상 학령전기, 학령기 아동의 수두 발생에서 또래집단이 감염원이 될 가능 성이 높기 때문에 거주지 주소를 기반으로 근접도 지표를 생성한 것에는 한계가 존재한다. 그러나 실무적으로 모든 수두 사례에서 소속 유치원이나 학교를 조사할 수 없다는 한계점과 아동들의 소속 유치원이나 학교가 거주지 근방이 라는 점을 고려한다면 거주지 주소를 기반으로 한 분석은 현실적인 대안이 될 수 있다. 학령기 아동의 수두 발생 사례 의 경우 거주지 주소를 기반으로 배정되는 초등학교 정보를 학구도안내서비스로부터 획득하여 실무자에게 실시간으로 제공하는 방법도 유행 판별을 위해 도움이 될 수 있다[13]. 세 번째로 이 연구에서는 근접도 산출을 위한 기준거리인 학령전기, 학령기 아동의 통상생활반경에 대한 기존의 연구 결과를 찾을 수 없었기 때문에 $1 \mathrm{~km}$ 로 임의로 설정하였다. 따라서 아동의 통상생활반경에 대한 근거 있는 값을 근접도 를 결정하는 기준을 설정하면 더 정확한 분석 결과를 얻을
수 있을 것으로 추측된다. 그러나 통상생활반경을 $1 \mathrm{~km}$ 로 설 정하여 산출된 지표도 수두 발생의 양상을 파악하는데 사용 될 수 있었으며, 통상생활반경이 변하더라도 지표 값이 상대 적으로 변화할 뿐이므로 현재의 기준으로 지표를 산출하더 라도 지표 개발의 목적을 벗어나지는 않는다고 생각한다. 그러나 이 연구에서의 결과는 대구와 같은 시 단위의 분석에 서 일반적으로 사용될 수 있을 것으로 보이지만 분석대상이 경상북도와 같이 인구밀도가 상대적으로 낮거나 시·군·구와 같은 하부 행정 구역을 가지고 있는 경우에 사용될 수 없을 수 있으므로, 이에 대한 추가적인 연구가 필요하다. 이 연구에 서는 수두 발생 사례 간의 거리를 계산함에 있어서 다소 복잡 한 계산식을 사용하였지만 법정감염병이 시·도 단위에서 관 리되고 있다는 점을 착안한다면 분석의 대상이 되는 지점들 간의 거리가 상대적으로 매우 가깝기 때문에 구체에서 호의 길이를 구하는 대신 유클리드 거리를 활용할 수 있다[10].

근접도 지표를 2016년 대구 지역 수두 발생 사례에 적용하 여 분석했을 때 여름과 겨울에 수두 발생이 증가하고, 봄과 가을에 수두 발생이 감소하는 것과 다르게 봄과 여름의 수두 는 근접도가 높으며, 가을과 겨울의 수두는 근접도가 낮은 것으로 확인되었다. 따라서 수두 발생이 많고 적음과 근접도 의 높고 낮음에 따라 총 4 가지 유형의 수두 발생 양상을 발견 할 수 있었다. 먼저 Fig. 2B는 2016년 봄 대구 지역의 수두 발생 사례와 근접도에 대한 선 도표와 산점도이다. 분석 기준 일의 수두 신규 보고는 4건이었으며, 21일 이내의 발생한 수두의 위치로부터 멀리 떨어져 있지 않아 근접도는 3.25 로 수두 보고 건수와 유사한 수준이었다. 따라서 이 시기에는 수두 보고가 많지 않았으나 주로 기존의 수두 보고 지역으로 부터 인접한 곳에서 신규 발생 보고가 있었던 시기이므로 수두에 대한 통상 수준의 감시를 유지하고 예방 홍보활동을 시행하는 것이 수두의 신규 발생 관리에 도움이 될 것으로 판단된다. 두번째 유형인 Fig. 2C는 2016년 여름과 같이 일 별 수두 발생(15건)이 많지만 그 근접도(12.33)가 높은 것으 로 확인되어 좁은 구역 또는 기존 수두 발생지역과 인접한 지역에 많은 수의 수두가 보고되는 유형이다. 이러한 유형은 개별 수두 발생보다는 유행 사례에 가깝다고 판단될 수 있으 므로 해당 지역에 대한 역학조사 실시 등으로 발생 지역에 대한 집중 감시가 수두의 확산을 방지하는데 도움이 될 것으 로 판단된다. 세 번째 유형인 Fig. 2D는 2016년 가을에 관찰 된 형태로 일별 수두 발생 수는 적지만(6건) 근접도(1.33)가 낮은 경우로 산점도에서 확인되는 바와 같이 소수의 수두 발생이 기존 발생 지역과 무관하게 넓은 범위에서 발생하는 
유형이다. 이러한 형태의 수두 발생의 분포는 광범위한 지역 에 대규모 유행으로 이어질 수 있다고 판단되므로 수두 예방 을 위한 대대적 시민 홍보 활동과 의료기관에 대한 신고독려 를 통해 유행을 조기에 차단하려는 노력을 기울일 필요가 있다. 마지막 유형은 Fig. 2E와 같이 일별 수두 발생(17건)이 많고 근접도(7.18)는 낮은 경우로 산점도에서처럼 많은 수의 수두가 기존 발생지역과 인접하지 않은 채 동시다발적으로 발생하는 유형이다. 이때는 개인 단위의 위생철저를 위한 홍보활동과 수두에 감염된 환자의 격리에 노력을 기울일 필 요가 있다고 판단된다.

수두 바이러스는 인체의 외부에서 그리 오래 생존하지 못 하는 것으로 알려져 있으며 고온의 환경에서 감염력을 더 빨리 잃지만 낮은 상대습도에서는 더 오래 생존할 수 있는 것으로 보고되어 있다[14,15]. 수두 발생이 근접도에 따라 봄여름과 가을-겨울로 구분될 수 있었기 때문에 수두 바이 러스의 병태생리를 파악하거나 감염의 전파에서 환경적 요 인과의 관련성을 찾기 위해서 근접도 지표가 활용할 수 있을 것으로 판단된다.

법정감염병 중 하나인 수두의 예방 및 관리를 위해서 의료 기관 등은 수두 의사, 확진 사례에 대해서 신고의 의무가 있고 관할 시·도 역학조사관은 개별 신고 사례로부터 유행을 의심하여 조사할 의무가 있음에도 불구하고 지금까지의 신 고·보고 체계하에서는 실제로 수두의 유행 사례를 구분하는 것이 어려웠다. 이 연구에서는 기존에 수두 신고 체계하에서 확보되는 정보로부터 수두의 유행을 추측하는데 도움이 될 수 있는 새로운 지표를 개발하고 지표에 따른 수두 관리 방안 을 제시하였다. 또한, 개발된 지표를 활용해 수두의 새로운 역학적 특성을 발굴하였다.

\section{CONFLICT OF INTEREST}

No potential conflict of interest relevant to this article was reported.

\section{ORCID}

Kiwook Yang, https://orcid.org/0000-0003-1656-5930

Incheol Seo, https://orcid.org/0000-0002-3271-381X

\section{REFERENCES}

1. Korea Centers for Disease Control \& Prevention. National childhood vaccination coverage among children aged 3 years in Korea [Internet]. 2016 [cited 2017 Jul 28]. http://cdc.go.kr/ CDC/info/CdcKrinfo0726.jsp?menuIds=HOME001-MNU1 132-MNU2430-MNU2689\&fiid=9254\&q type $=$ \&q value $=\& c i d=75612$ \&pageNum=/. Korean.

2. Korea Centers for Disease Control \& Prevention. Infectious diseases surveillance yearbook [Internet]. 2016 [cited 2017 Jul 28]. http://www.cdc.go.kr/CDC/info/CdcKrInfo0302.jsp? menuIds=HOME001-MNU1132-MNU1138-MNU0038\&fi

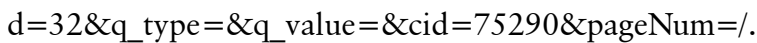
Korean.

3. Heininger U, Seward JF. Varicella. Lancet 2006;368:1365-76.

4. Jit M, Brisson M. Modelling the epidemiology of infectious diseases for decision analysis. Pharmacoeconomics 2011;29: 371-86.

5. Korea Centers for Disease Control \& Prevention. Guideline for the management of vaccine-preventable diseases [Internet]. 2017 [cited 2017 Jul 28]. http://www.cdc.go.kr/CDC/notice/ CdcKrTogether0302.jsp?menuIds=HOME001-MNU1154MNU0005-MNU0088\&cid=74163/. Korean.

6. Ministry of Health and Welfare. Infectious disease control and prevention act [Internet]. 2015 [cited $2017 \mathrm{Jul}$ 28]. https:// elaw.klri.re.kr/kor_service/lawView.do?lang=ENG\&hseq $=3$ 72398joseq=JO0002000

7. Korea Centers for Disease Control \& Prevention. Integrated disease $\&$ health management system [Internet]. 2015 [cited 2017 Jul 28]. http://is.cdc.go.kr/. Korean.

8. Team RC. R: a language and environment for statistical computing. Vienna, Austria: R foundation for statistical computing; 2014.

9. Kahle D, Wickham $H$. ggmap: spatial visualization with ggplot2. R J 2013;5:144-61.

10. Mwemezi JJ, Huang Y. Optimal facility location on spherical surfaces: algorithm and application. New York Sci J 2011;4: 21-8.

11. Anselin L, Bera AK. Spatial dependence in linear regression models with an introduction to spatial econometrics. In: Ullah A, Giles DEA, editors. Handbook of applied economic statistics. New York: Marcel Dekker; 1998. p. 237-90.

12. Lee J, Wong DWS. Statistical analysis with ArcView GIS. New York: John Wiley; 2001.

13. Ministry of Education. Schoolzone service [Internet]. 2016 [cited 2017 Jul 28]. https://schoolzone.edumac.kr/. Korean.

14. Tang JW. The effect of environmental parameters on the survival of airborne infectious agents. J R Soc Interface 2009: 6(Suppl 6):S737-46.

15. Arvin AM, Gershon AA. Varicella-zoster virus: virology and clinical management. Cambridge, UK; New York: Cambridge University Press; 2000. 
Kiwook Yang and Incheol Seo

\section{APPENDIX}

\section{1. 신규 보고된 수두와 분석 기준일로부터 21일 이내의 수두 사례 추출에 사용된 함수}

while(), mapply(), cbind(), as.data.frame()

\section{2. 산점도 및 밀도 도표 작성에 사용된 함수}

ggplot(). stat_density2d(), scale_fill_gradientn(), scale_alpha_continous(), scale_y_continuous(), scale_x_continuous()

\section{3. 위도, 경도를 이용하여 두 지점 간의 거리를 구하기 위해 R에서 작성된 함수}

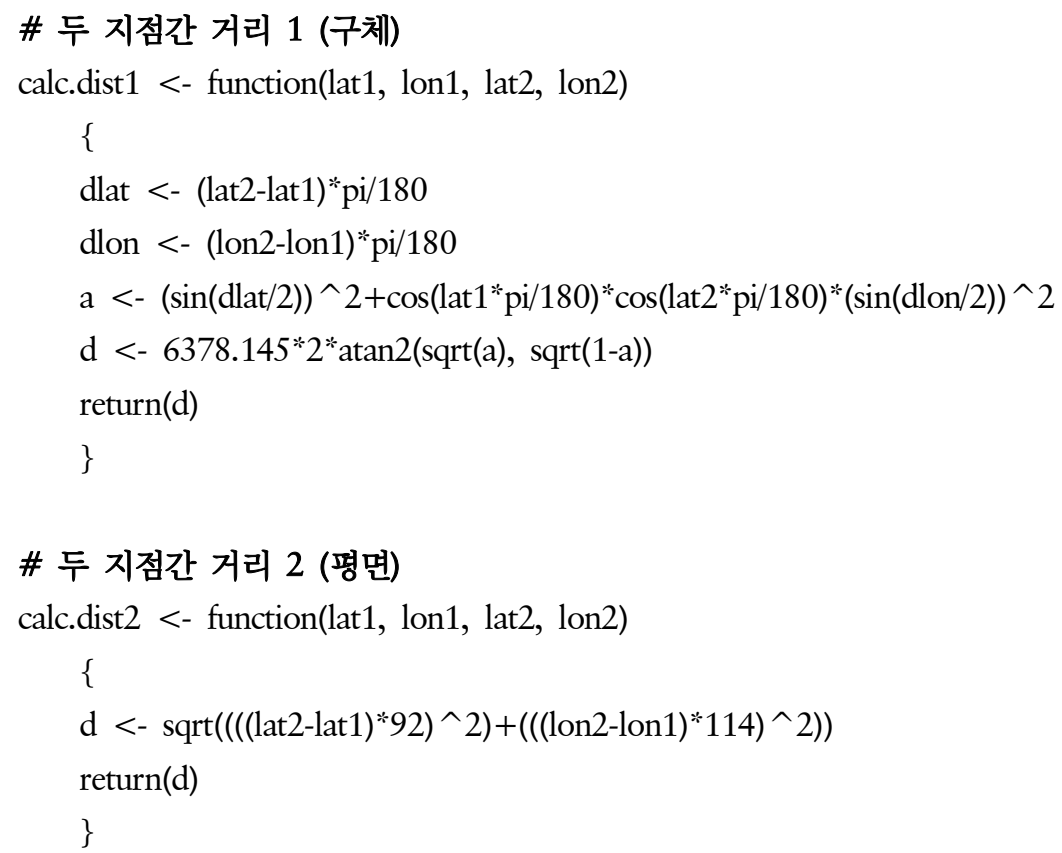

